\title{
Does Integrated Reporting Approach Enhance the Value Relevance of Accounting Information?: Evidence from Asian Firms
}

\author{
Kenny Fernando ${ }^{1 *}$, Rina Dharmawati ${ }^{1}$, Dewi Sriani ${ }^{1}$, Elvia R. Shauki ${ }^{1}$, Vera Diyanty ${ }^{1}$ \\ ${ }^{1}$ Faculty of Economics and Business, Universitas Indonesia, Depok 16424, Indonesia \\ *Corresponding Author: kennyfernando14@gmail.com
}

\begin{abstract}
This study aims to investigate the effect of Integrated Reporting $(<\mathrm{IR}>)$ on the relevance of accounting information: evidence from ASIA. By conducting regression analysis on 195 firm-years from listed companies on The International Integrated Reporting Council between 3 years. $<\mathrm{IR}>$ is measured by coverage ration of keywords using NVIVO Software Version 11. The results shows that impelementation of $<\mathrm{IR}>$ has no effect on the relevance of accounting information.
\end{abstract}

Keywords: Integrated Reporting; Value Relevance; Accounting Information; NVIVO.

\section{INTRODUCTION}

The development of corporate reporting has attracted much attention from practitioners, policy makers, and investors. Currently, this development has reached a new stage of value creation issues after the emergence of the sustainability trend ${ }^{1}$. On 9 December 2013, the International Integrated Reporting Council (IIRC) released a framework called Integrated Reporting $<\mathrm{IR}>$ which consists of fundamental concepts, guiding principles, and the content element as a business model to communicate about how organizational strategy, governance, performance, and prospects lead to the value creation in the short, medium, and long term ${ }^{2}$. Mervyn King, the Chairman of IIRC and Chairman of the King Corporate Governance Committee ${ }^{3}$ stated that $<\mathrm{IR}>$ provides an opportunity for companies to present their business clearly and concisely in an integrated manner.

The evolution of $<\mathrm{IR}>$ that gives benefits for companies in each phase led many international firms in different countries, such as Brazil, Japan, Australia, Germany, South Africa, Netherlands, Canada, the United States, the United Kingdom, and others, to adjust their regulations and policies and follow IIRC, although not all the countries take the same action. Many companies in Asia that are members of IIRC also recognized these facts and obtained advocacy in $<\mathrm{IR}>$ implementation. Indeed, starting from 2014, there were 106 companies in Asia as official members of IIRC ${ }^{27}$. However, the adoption of the $<\mathrm{IR}>$ approach raised the question of the enhancement of the value relevance of financial information. To date, it has been an empirical question because the applications of accounting standards showed no difference either pre or post the $<\mathrm{IR}>$ adoption period ${ }^{4-6}$.

Previous research has focused on the results and benefits of $<\mathrm{IR}>$ implementation when compared to the current reporting, such as sustainability reporting ${ }^{7,8}$. Thus, there is still little research on the value relevance of $<\mathrm{IR}>$. One of the most interesting research agendas that have to be investigated by the researcher is about the value relevance of $<\mathrm{IR}>$ adoption as the latest evolution of corporate reporting in the world, irrespective of whether there is a market reaction from the adoption of this $<\mathrm{IR}>$ approach $^{5}$. A study conducted in South Africa and found that $<\mathrm{IR}>$ adoption enhanced the value relevance of accounting information as reflected in earning per share (EPS) ${ }^{9}$. On the other hand, another research did not show a causal relationship, but suggested the possibility of a positive relationship between company reporting and stock prices ${ }^{10}$. This gap encourages us to examine the effect of the adoption of $<\mathrm{IR}>$ on the value relevance of accounting information, particularly in Asian firms where this adoption is still voluntary.

\section{LITERATURE REVIEW AND HYPOTHESIS DEVELOPMENT}

\section{Signaling Theory}

Signaling theory has been used in many studies, especially those related to corporate finance ${ }^{11,12}$ and human behavior ${ }^{13,14}$. Various kinds of analyses explain that $<\mathrm{IR}>$ and its credibility will give the signal that the organization is taking steps to meet the information expectations of various stakeholder groups. The implementation of $<\mathrm{IR}>$ provides a more useful signal that a company is providing a better quality of information 
for the investor community. $<\mathrm{IR}>$ provides information on the relationships between the various measures, both operational and organizational strategies, as a complement of financial statements ${ }^{6}$.

\section{Stakeholder Theory}

Stakeholder theory is a theory that reflects a company's accountability to stakeholders ${ }^{15}$. $<$ IR $>$ is closely related to the stakeholders, especially the concept of value creation, which plays a significant role for the sustainability of the company ${ }^{16}$. The $<\mathrm{IR}>$ concept provides the requirement to integrate all information related to social, economic, and environmental issues, as well as the socio-political and global economic subsystems. This approach will make investors more informed and better able to assess the economic value of the company. The concept of $<\mathrm{IR}>$ has shifted the corporate responsibility that was initially measured by the economic indicators in financial reporting to social factors or social dimensions to stakeholders, both internal and external. All of these aspects can be communicated through $<\mathrm{IR}>$ adoption, regardless of the cost incurred in the reporting process.

\section{The Concept of Integrated Reporting $<$ IR $>$}

The $<\mathrm{IR}>$ approach aims to explain how the organization creates value over time for the financial capital provider and the ways of prioritizing information required by investors, so it can improve the usefulness of financial reporting to investors through the enhancement of the value relevance of accounting information ${ }^{2}$. One aspect that distinguishes $<\mathrm{IR}>$ from another approach is its purpose in presenting concise information reflecting material aspects of the organization, including social, environmental, and economic outcomes, opportunities, and risks in an integrated manner through organizational reporting ${ }^{17}$. The potential impact of this value relevance generated by $<\mathrm{IR}>$ can improve the quality of reporting ${ }^{18-20}$. The above explanations conclude that the $<\mathrm{IR}>$ approach is expected to enhance the usefulness of corporate reporting for the stakeholders through its value relevance.

\section{Hypotheses Development}

The Financial Accounting Standards Board stated that the most important characteristics of financial statements are reliability and relevance ${ }^{21}$. Value relevance theory argues that the role of accounting information lies in the aspect of valuation of equity, especially how a firm's value can be explained or attributed by accounting information ${ }^{22}$. Financial information is said to be relevant if it is associated with the market value ${ }^{22}$. Several studies related to $<\mathrm{IR}>$ have been examined, but those studies are still in the embryonic or new stage ${ }^{5}$. Previous studies have focused more on the descriptions of the results, benefits, and critics of $<\mathrm{IR}>$ implementation ${ }^{7,8,24}$.

One of the most interesting research agendas that have to be examined by researchers relating to $<\mathrm{IR}>$ is the value relevance of $\left\langle\mathrm{IR}>\right.$ adoption or whether there is a subsequent market reaction ${ }^{5}$. In previous studies, the potential impact of $<\mathrm{IR}>$ on the relevance of financial reporting has been acknowledged ${ }^{20}$. Studies ${ }^{25}$ related to the value relevance of disclosure provide indirect evidence to support high quality integrated reports developed by IIRCSA $^{28}$ and IIRC $^{2}$, so those results still raise a major question. There is no causal relationship, but suggested the possibility of a positive relationship between corporate reporting and stock prices ${ }^{10}$.

According to some researchers, the adoption of $<\mathrm{IR}>$ will also improve the quality of financial reporting ${ }^{18-20}$. Research on the enhancement of value relevance of accounting information in $<\mathrm{IR}>$ is supported by empirical evidence regarding the Johannesburg Stock Exchange (JSE) where $<\mathrm{IR}>$ adoption became mandatory ${ }^{9}$. The results of this study indicate that there is a significant increase in the value relevance of accounting information after the adoption of $<\mathrm{IR}>$, which is reflected in EPS. This study concludes that $<\mathrm{IR}>$ has an effect on the enhancement of the value relevance.

Based on the above literature, we developed a research hypothesis as follows:

H1: The adoption of Integrated Reporting $<\mathrm{IR}>$ has an effect on the value relevance of the accounting information.

\section{RESEARCH METHOD}

\section{Research Method}

This research uses a mixed method approach (quantitative and qualitative methods). Financial variables were obtained from Datastream Thomson Reuters, while the qualitative approach was used in the stage of non-financial data collection about the percentage of $<\mathrm{IR}>$ components obtained by using content analysis for companies' annual reports with NVIVO software. This approach followed the method used a coverage ratio in the corporate reporting disclosure $^{26}$. We used 300 specific keywords guided by the framework of the Integrated Reporting $<$ IR $>$ elements. All those variables were then tested by fixed effect regression using STATA software.

\section{Data Analysis}

We obtained the sample from companies registered as a member of IIRC to avoid bias in the sample selection. We used only Asian firms based on the consideration that firms in the Asian region have a similar business 
environment and cultural background to firms in Indonesia. In addition, $<\mathrm{IR}>$ adoption for both Asian and Indonesian companies is voluntary. The total sample was 106 companies. Then, we used several criteria to choose the final sample so it was more relevant. With the elimination of some companies based on the sample criteria, the final sample used in this study is 65 companies or 195 firm years' observation.

We used the Linear Price Level model to measure the effectiveness of $<\mathrm{IR}>$ adoption based on the changes in the market value of equity ${ }^{9}$. This model has also been used by other researchers ${ }^{29-33}$.

$P R_{i t}=\propto_{0}+\propto_{1} B V S_{i t}+\propto_{2} E P S_{i t}+\propto_{3} P I R_{i t}+\propto_{4}(P I R * B V S)_{i t}+\propto_{5}(P I R * E P S)_{i t}+\propto_{6}$ LOSS $_{i t}+$ $\propto_{7}(L O S S * E P S)_{i t}+\propto_{8} L E V_{i t}+\propto_{9} R O E_{i t}+\propto_{10} S I Z E_{i t}+\varepsilon_{i t} \ldots \ldots$ (1)

The dependent variable in this study is the market value of equity (PR), which is calculated by dividing the market value of equity in the fifth month after the fiscal year $(t+5)$ by the number of shares oustanding. The fifth period $(t+5)$ after the fiscal year is used because the purpose of this study is to know the investor reaction, which is not possible if the market value of equity is seen at the end of the year. This measurement has also been used in previous research ${ }^{9}$.

The main independent variables include book value per share (BVS), earnings per share (EPS), and percentage of $<\mathrm{IR}>$ content (PIR). The BVS is measured by dividing the book value of equity by the number of shares, while the EPS is measured by dividing earnings before interest and tax (EBIT) by the number of shares. Meanwhile, the disclosure of PIR is measured by the coverage ratio of the 300 keywords in each company's annual report. The keywords used are derived from the framework of $<\mathrm{IR}>$ and follow the method from Verbetten ${ }^{26}$, shown in table 3.1. We also interact the PIR*BVS and PIR*EPS to gain the results about the effect of $<$ IR $>$ on firms' EPS and BVS.

In this study, we used four control variables because they are often used in research related to market valuation'. The corporate loss (LOSS) is measured using binary variables, which is one (1) if the EPS is negative and zero (0) otherwise. The companies' debt ratio is measured by dividing the total debt by total assets while the company's profitability ratio is measured by dividing EBIT by the book value of equity, and firm size is measured by the total asset logarithm.

\section{RESULTS AND DISCUSSIONS}

The result of the descriptive statistics is shown in Table 1. The average market value of equity (PR) for three years is $¥ 2,478$ with the standard deviation of $¥ 2.782$. This means that the sample has a market value of equity (PR) that does not differ much among the sample companies. The mean of BVS of the entire sample is $¥ 1,552.00$ for three years. The growth of those companies is unequal, which is shown by the deviation standard in a higher value than the average (¥ 1869.31). The EPS of all sample companies over three years has an average of $¥ 227.09$. Most of the sample companies have increased performance compared to other sample companies.

Table.1. Description Statistic

\begin{tabular}{lllll}
\hline \multicolumn{1}{c}{ Variable } & \multicolumn{1}{c}{ Mean } & \multicolumn{1}{c}{ Std. Dev. } & \multicolumn{1}{c}{ Min. } & \multicolumn{1}{c}{ Max. } \\
\hline PR & 2.478 & 2.782 & 0.002 & 17.185 \\
BVS & 1552.003 & 1869.310 & 3.922 & 14695.787 \\
EPS & 227.092 & 383.927 & -144.513 & 3718.684 \\
PIR & 0.095 & 0.068 & 0 & 0.173 \\
LEV & 0.520 & 0.185 & 0.116 & 0.875 \\
ROE & 0.120 & 0.168 & -1.862 & 0.429 \\
SIZE & 20.582 & 1.384 & 17.600 & 23.699 \\
\hline
\end{tabular}

The mean of the $<\mathrm{IR}>$ coverage (PIR) ratio is $9.5 \%$. This means that of the 1,000 words in the annual report, there are only 95 keywords with an $<\mathrm{IR}>$ element, thus indicating that the $<\mathrm{IR}>$ coverage is quite low. The companies' debt ratio (LEV) averages at $52 \%$ with the maximum value witnessed by Toshiba Ltd (87.5\%). In addition, the average company profitability ratio (ROE) is $12 \%$ with a deviation standard of $16.8 \%$. The firm size (SIZE) had an average of $¥ 20.58$ over three years, with a deviation standard of $¥ 1.38$. This suggests that the sample firms varied in size.

This study performs a fixed effect regression with STATA as the best model to avoid the heteroscedasticity and autocorrellation problems using Stata 12. Table 2 shows the findings on of the main models. The result of the main coefficient is reflected in the coefficients $\alpha 1$ and $\alpha 2$. This result shows that the value relevance of accounting information reflected in BVS (Book Value of Stock Equity) and EPS has positive and significant coefficients. The coefficient of BVS is 0.002 , and this is statistically significant at the $1 \%$ level, while the coefficient of EPS is 0.004 and this is significant at the 5\% level. This finding indicates that the values of BVS and EPS have a positive effect on the value relevance of accounting information, which is reflected in the stock price. This result confirms the 
company's value measurement model through BVS and EPS from Ohlson ${ }^{34}$ as the basic model for calculating the market value of the firm's market equity.

Regarding the effect of $<\mathrm{IR}>$ on the relevance of firm value, the result is shown in the coefficients of $\alpha 3, \alpha 4$, and $\alpha 5$. The coefficient $\alpha 3$, i.e., PIR, has a negative value $(-0.306)$, but it is not significant ( $p$ value $=0.760)$. On the other hand, the interaction coefficient on the PIR x BVS variable has a positive value with a value of 0.001 , but it is not statistically significant ( $p$ value $=0.316$ ). This finding shows that $<\mathrm{IR}>$ adoption does not affect the value relevance of the company as reflected in the book value of stock price (BVS). On the other hand, the value relevance of EPS decreased after $<\mathrm{IR}>$ adoption, but it is also not significant. This is shown in the coefficient PIR*EPS, which is negative $(-0.0039$, $p$ value $=0.639)$. Based on these explanations, the evidence of the results of this study indicates that the adoption of voluntary $<\mathrm{IR}>$ in Asian firms does not have a significant effect on the value relevance of accounting information, so hypothesis 1 (H1) is not accepted.

Table.2. Regression

\begin{tabular}{|c|c|c|c|}
\hline Variable & Coefficient & T-stat. & $\mathrm{p}$-value \\
\hline BVS & 0.002 & 3.50 & $0.000 * * *$ \\
\hline EPS & 0.004 & 1.73 & $0.063 * *$ \\
\hline PIR & -.306 & -0.20 & 0.760 \\
\hline PIR*BVS & 0.001 & 0.81 & 0.316 \\
\hline PIR*EPS & -0.003 & -0.36 & 0.639 \\
\hline LOSS & 0.965 & 1.88 & 0.422 \\
\hline LOSS*EPS & 0.012 & 0.85 & 0.397 \\
\hline LEV & 4.376 & 1.49 & 0.143 \\
\hline ROE & -2.020 & 0.87 & 0.383 \\
\hline SIZE & -2.626 & -2.06 & $0.041 * *$ \\
\hline
\end{tabular}

These results indicate that $<\mathrm{IR}>$ does not affect the value relevance of the accounting information. Although the results show that the coefficient of PIR*EPS is positive, it is not statistically significant. The results of this study are in line with the findings in the study ${ }^{10}$, which found that there is no causal relationship, but shows the possibility of a positive relationship between corporate reporting and stock price.

These insignificant results indicate certain possibilities because of the new adoption of the $<\mathrm{IR}>$ approach by Asian firms; the impact of its implementation is still to be examined. This study uses a short window, that is, 1 year before and 1 year after the adoption of IR so the researcher is not able to see the impact of $<\mathrm{IR}>$ in the long run. In addition, the implementation of $<\mathrm{IR}>$ is still in its infancy and has not been widely adopted by most companies in Asia. The Asian countries as members of the IIRC produced 106 companies, and the majority of these companies came from Japan. This suggests that the widespread adoption of this latest financial reporting trend has not been widely implemented in other countries in Asia, or in other words, this distribution has not been diffused. One of the reasons for this is that the implementation of sustainability reporting is still seen as the most important reporting practice in the company's business processes; hence, it is not considered important for the company to adopt $<\mathrm{IR}>$. In addition, there is no regulation, sanctions, or lack of power from IIRC related to the implementation of the $<\mathrm{IR}>$ approach. This is also supported by the findings that the financial information used as an indicator in the value relevance of $<\mathrm{IR}>$ is distorted by the implementation of relatively similar accounting standards at pre and post $<\mathrm{IR}>$ adoption $^{4-6}$. These factors cause there to be no effect on the value relevance of financial information after $<\mathrm{IR}>$ adoption.

These results differ from the findings that examined the mandatory $<\mathrm{IR}>$ adoption in the JSE in South Africa over a longer period, that is, between 2008-2013 using a dummy variable for $<\mathrm{IR}>{ }^{9}$. These results found that the implementation of $<\mathrm{IR}>$ affects the value relevance of accounting information. The concept of $\langle\mathrm{IR}>$ with its value creation and distribution is important in order to carry out a firm's responsibilities for managing resources and improving the welfare of their stakeholders. Based on this, the implementation of $<\mathrm{IR}>$ provides a good signal that is more useful in offering a better quality of information for the investor community ${ }^{6}$. If we connect this finding with signaling theory, this theory states that the adoption of $<\mathrm{IR}>$ provides a good signal and is useful in providing a better quality of information to be used by investors in their decision making ${ }^{6}$. However, the results show a contradiction between mandatory $<\mathrm{IR}>$ implementation, such as in South Africa ${ }^{9}$, and voluntary adoption, as we have done in this paper.

Our results show that the market does not respond the adoption of $<\mathrm{IR}>$ by company. However, there is a possibility that the response has not been seen because of the short window in this research and for other reasons, as explained above. The implementation of $<\mathrm{IR}>$ accommodates the interests not only of the investors, but also of the other stakeholders, such as management. Management plays an important role in managing the company's resources including the reporting of corporate performance. In this case, the implementation of $<\mathrm{IR}>$ is one of the investment for the company in terms of conveying the information to the stakeholders. This is in accordance with 
stakeholder theory, which states that management is obliged to provide useful information to support the decision making. While the implementation of $<\mathrm{IR}>$ faces constraints such as costs, companies in the Asian region are still committed to implementing $<\mathrm{IR}>$ by registering as IIRC members. Such actions are believed to have an impact on the stakeholders even though this paper concludes the contradictive results in the value relevance enhancement.

\section{CONCLUSION}

This study aims to investigate the effect of $<\mathrm{IR}>$ on the value relevance of the accounting information. This study was carried out using 195 firm years' observation as the members of IIRC. The results revealed that $<$ IR $>$ adoption has no effect on the value relevance of the accounting information. This is due to several factors, including the following: (1) there is the possibility that the reaction of the market is still not seen in the short window (1-year post adoption) in Asian firms, (2) the nature of the voluntary implementation of $<$ IR $>$ lacks force and differs from the mandatory adoption in South Africa, and (3) the accounting standards are relatively similar before and after $<\mathrm{IR}>$ adoption.

This study has some limitations. First, the samples are limited to the Asian companies registered as IIRC members because of the limited time and resources for this research. Therefore, the results of this study cannot be generalized widely for voluntary $<\mathrm{IR}>$ adoption in the world which comprises 467 companies. Second, the period used in this study is limited to a short range (3 years) starting from 1 year prior to $<\mathrm{IR}>$ adoption, adoption year, and 1 year after $<\mathrm{IR}>$ adoption. $<\mathrm{IR}>$ adoption is still fairly new in Asian firms, so a longer period is not possible; hence, this result does not reflect the long-term effect of $<\mathrm{IR}>$ adoption. There is a chance that a longer period may give different results. For further research, it would be useful use additional samples with a wider coverage of $<\mathrm{IR}>$ adoption in the world and with a longer period of study (longer window).

\section{REFERENCES}

[1] Ernst \& Young. EY's Excellent in Integrated Reporting Awards 2013. Ernst \& Young, Pretoria (2013).

[2] The International Integrated Reporting Council (IIRC). The International Integrated Reporting Framework. The International Integrated Reporting Council (IIRC), London (2013).

[3] Black Sun Plc. Understanding Transformation: Building the Business Case for Integrated Reporting. Black Sun Plc, London (2012).

[4] M Cheng, W Green, P Conradie, N Konishi, A Romi. The international integrated reporting framework: Key issues and future research opportunities. Journal of International Finance Management \& Accounting, 25(1) (2014) 90-119.

[5] C de Villiers, L Rinaldi, J Unerman. Integrated Reporting: Insights, gaps and an agenda for future research. Accounting, Auditing \& Accountability Journal, 27(7) (2014) 1042-1067.

[6] J Solomon, W Maroun. Integrated Reporting: The Influence of King III on Social, Ethical and Environmental Reporting. The Association of Chartered Certified Accountants, London (2012).

[7] R Hampton. Brace Yourself: More Regulatory Changes. Accountancy SA, May (2012).

[8] A Watson. Financial Information in an Integrated Report: A Forward Looking Approach. Accountancy SA, December (2011).

[9] D Baboukardos, G Rimmel. Value relevance under Integrated Reporting approach: A research note, Journal of Accounting and Public Policy, 35(4) (2016) 437-452.

[10] PW Buys, S Van Rooyen, P Bosman. Do socially conscious companies provide better financial performance? An exploratory study. Studia Universitatis Babes Bolyai, 1 (2009) 3-15.

[11] G Dionne, K Ouederni. Corporate risk management and dividend signaling theory, Finance Research Letters, 8(4) (2011) $188-195$.

[12] HY Ching, F Gerab, T Toste. Scoring sustainability reports using GRI indicators: A study based on ISE and FTSE4 good price indexes. Journal of Management Research, 6(3) (2014) 27-48.

[13] JD Wells, JS Valacich, TJ Hess. What signals are you sending? How website quality influences perceptions of product quality and purchase intentions. MIS Quarterly, 35(2) (2011) 373-396.

[14] CH Gregory, AW Meade, LF Thompson. Understanding internet recruitment via signaling theory and the elaboration likelihood model. Computers in Human Behavior, 29(5) (2013) 1949-1959.

[15] RE Freeman. Strategic Management: A Stakeholder Approach. Pitman, Boston (1984).

[16] J Shaoul. The power of accounting: Reflecting on water privatization?. Accounting, Auditing \& Accountabiity Journal, 10(3) (1997) $382-405$.

[17] The International Integrated Reporting Council (IIRC). Understanding Transformation: Building the Business Case for Integrated Reporting. The International Integrated Reporting Council (IIRC), London (2012).

[18] SY Cho, C Lee, RJ Pfeiffer. Corporate social responsibility performance and information asymmetry. Journal of Accounting and Public Policy, 32(1) (2013) 71-83.

[19] A Middleton. Value relevance of firms' integral environmental performance: Evidence from Russia. Journal of Accounting and Public Policy, 34(2) (2015) 204-211.

[20] RG Eccles, I Ioannou, G Serafeim. The impact of corporate sustainability on organizational processes and performance. Management Science, 60(11) (2012) 2835-2857.

[21] Financial Accounting Standards Board (FASB). Electronic Distribution of Business Reporting Information. Steering Committee Report Series, Connecticut (2000).

[22] AA Al-Hogail. The Valuation Effect of Investor Behavior on the Relevance of Financial Information. Working Paper, Case Western Reserve University (2004).

[23] ME Barth, WH Beaver, WR Landsman. The relevance of the value relevance literature for financial accounting standard setting: Another view. Journal of Accounting and Economics, 31(1-3) (2001) 77-104.

[24] S Adams, R Simnett. Integrated reporting: An opportunity for Australia's not-for-profit sector. Australian Accounting Review, 21(3) 
(2011) 292-301.

[25] M de Klerk, C de Villiers. The value relevance of corporate responsibility reporting: South African evidence. Meditari Accountancy Research, 20(1) (2012) 21-38.

[26] FHM Verbeeten, R Gamerschlag, K Möller. Are CSR disclosures relevant for investors? Empirical evidence from Germany. Management Decision, 54(6) (2016) 1359-1382.

[27] The International Integrated Reporting Council (IIRC). Strategy: The Breakthrough Phase. The International Integrated Reporting Council (IIRC), London (2016).

[28] Institute of Directors in Southern Africa. King Report on Governance for South Africe. Institute of Directors in Southern Africa, Pretoria (2009).

[29] S Berthelot, M Coulmont, V Serret. Do investors value sustrainability reports? A canadian study. Corporate Social Responsibility and Environment Management, 19(6) (2012) 355-363.

[30] L Hassel, H Nilsson, S Nyquist. The value relevance of enviromental performance. European Accounting Review, 14 (1) (2005) $41-61$.

[31] D Johnston. An investigation of regulatory and voluntary environmental capital expenditure. Journal of Accounting and Public Policy 24(3) (2005) 175-206.

[32] IC Lourenco, JL Callen, MC Branco, JD Curto. The value relevance of reputation for sustainability leadership. Journal of Business Ethics, 119(1) (2014) 17-28.

[33] C Sinkin, CJ Wright, RD Burnett. Eco-efficiency and firm value. Journal of Accounting and Public Policy, 27(2) (2008) 167-176.

[34] JA Ohlson. Earnings, book values, and dividends in security valuation. Contemporary Accounting Research, 11(2) (1995) $661-687$. 